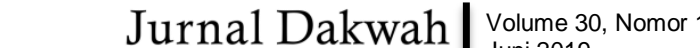 \\ Juni 2019 \\ P-ISSN: $1412-0348$ \\ E-ISSN: 2654-3877
}

DOI: $10.24014 /$ jdr.v30i1.6450

\section{PENGEMBANGAN KEILMUAN PROGRAM STUDI JURNALISTIK ISLAM MELALUI MATA KULIAH PEACE JOURNALISM}

\author{
Asad Isma \\ UIN Sulthan Thaha Saifuddin Jambi \\ Email: asadisma@uinjambi.ac.id
}

\section{Kata kunci}

Program Studi

Jurnalistik Islam,

Peace Journalism
Keywords

Department of islamic journalism, Peace Journalism

\begin{abstract}
Abstrak
Penelitian ini mencoba untuk menawarkan model pengembangan keilmuan Program Studi Jurnalistik Islam melalui pendekatan peace journalism. Peneliti melihat pentingnya peace journalism (jurnalisme damai) untuk diperkenalkan, dipahami dan menjadi landasan kerja jurnalistik para jurnalis, terutama bagi mahasiswa. Penelitian ini menggunakan metode penelitian mixed methods yaitu menggabungkan antara penelitian lapangan, kepustakaan (library research) dan dilengkapi dengan research on the internet. Pentingnya pengembangan keilmuan prodi jurnalistik islam melalui peace journalism dapat dilihat dari adanya kebutuhan profesi jurnalisme yang semakin meningkat. Strategi pengembangan keilmuan Program Studi Ilmu Jurnalistik Islam UIN STS Jambi Melalui Mata Kuliah Peace Journalism dimulai dari perencanaan kurikulum, penyiapan sarana praktik dan pembelajaran berbasis pengalaman langsung.
\end{abstract}

\begin{abstract}
This study offers a scientific development model for department of islamic journalism through the approach of peace journalism. Researchers see the importance of peace journalism to be introduced, understood and become the basis of journalistic work of journalists, especially for students. This research uses mixed methods research method that is combining field research, literature and supplemented with online research. The importance of the scientific development of department of islamic journalism through peace journalism can be seen from the increasing need for journalism propositions. The scientific development strategy of the department of islamic journalism at UIN STS Jambi through the Peace Journalism Course starts from curriculum planning, preparation of practice facilities, and hands-on experience-based learning.
\end{abstract}


tokoh, Haris Sumadiria menyimpulkan bahwa secara teknis, jurnalistik adalah kegiatan menyiapkan, mencari, mengumpulkan, mengolah, menyajikan dan menyebarkan berita melalui media berkala kepada khalayak seluas-seluasnya dengan secepat-cepatnya. (Sumadiria, 2008).

Selain jurnalistik, ada istilah lain yang sering disandingkan dan dipadankan dengannya yaitu 'pers'. Samakah dua istilah tersebut? 'pers' berasal dari bahasa Belanda pers yang artinya menekan atau mengepres atau dalam bahasa Inggris disebut dengan press. Berdasarkan pengertian ini 'pers' berarti komunikasi yang dilakukan dengan perantaraan barang cetakan (Kusumaningrat \& Kusumaningrat, 2009). Unsur perantara ini yang kemudian menjadi poin pembeda dari jurnalistik, pers identik dengan hal-hal yang berhubungan dengan media (perantara) sedang jurnalistik lebih kepada sebuah proses kegiatan yaitu kegiatan mencari, menggali, mengumpulkan, mengolah, memuat dan menyebarkan berita melalui media berkala (Sumadiria, 2008). Meskipun demikian, perbedaan di antara keduanya tidak terlalu signifikan yang nantinya akan berpotensi mereduksi pengertian satu sama lain. Sebaliknya, jurnalistik dan pers memiliki pengertian yang sangat nyambung. Terlebih lagi, penggunaan dua istilah tersebut sudah membumi dalam percakapan sehari-hari sebagai dua hal yang satu.

Sesuai dengan pilar ke-4 demokrasi, pers harus memahami prinsip demokrasi dalam pemberitaannya. Oleh karena itu, aspek-aspek kedamaian, keadilan dan tidak melanggar HAM harus dikedepankan. Menurut Iswandi Syahputra dalam bukunya yang berjudul Jurnalisme Damai, Meretas Ideologi Peliputan di Area Konflik, konflik dapat muncul kapan saja dan di mana saja dan harus dibarengi dengan semangat kuat untuk memerangi konflik itu sendiri (Syahputra, 2006). Dalam bahasa yang lebih sederhana, peran media dalam memberitakan kasus-kasus pertikaian memiliki dua potensi yang sama besarnya, yakni memberikan kesempatan kepada kedua pihak yang berkonflik untuk menempuh jalan damai atau malah memperuncing keadaan atas pemberitaannya tersebut.

Ketegangan dan konflik sering menimbulkan kekerasan dan kekacauan di tengah-tengah masyarakat. Fenomena ini mengindikasikan integritas nasional yang mulai terancam. Kekerasan dan kerusuhan di beberapa wilayah Indonesia seakan-akan tak kunjung usai menjadi konsumsi pemberitaan sehari-hari. Konflik antar suku, ras, agama, kelompok dan antar golongan terus berkobar silih berganti dengan tidak sedikit membawa jatuh korban. Media massa cenderung mengeksploitasi aspek dramatik konflik demi penciptaan sensasi. Peran strategis pemberitaan media massa yang cenderung menciptakan potensi konflik akan menjadi signifikan untuk dibicarakan. Inilah keadaan dalam jurnalisme yang bukan 'damai'. Secara eksplisit, jurnalisme damai tujuannya untuk mempromosikan prakarsa perdamaian dari kubu manapun, dan untuk memungkinkan pembaca membedakan antara posisi-posisi yang dinyatakan oleh para pihak tersebut dan tujuan-tujuan mereka yang sebenarnya.

Para pekerja media bisa beralasan bahwa berita faktual dan sesuai dengan yang terjadi di lapangan. Memang benar berita itu adalah faktual tapi seyogyanya insan di bidang profesi penyiaran harus berada pada tanggung jawab etis yang mengacu Undang-Undang Penyiaran Nomor 32 Tahun 2012 dan Pedoman Perilaku Penyiaran dan Standar Program Siaran (P3SPS) (Masduki, 2007). Pada pasal 4 dijelaskan bahwa salah satu fungsi media adalah sebagai kontrol dan perekat sosial, sedangkan P3SPS pasal 23 butir (a) dijelaskan bahwa program siaran yang memuat kekerasan dilarang menampilkan secara detail peristiwa kekerasan, seperti tawuran, pengeroyokan, penyiksaan, perang, penusukan, penyembelihan, mutilasi, terorisme, pengrusakan barang-barang secara kasar atau ganas, pembacokan, penembakan dan/ atau bunuh diri. 
Pemberitaan yang melebih-lebihkan dengan maksud untuk membuat berita itu lebih heboh dan sensasional merupakan pelanggaran etis. Wartawan dengan mudah tergoda untuk memperuncing fakta-fakta dengan menghilangkan sebahagian berita, menfokuskan suatu detail yang kecil tetapi menyentil atau dengan memancing kutipan-kutipan yang provokatif, yang tujuannya bukanlah untuk mengatakan suatu kebenaran melainkan untuk menarik perhatian. Wartawan seperti inilah yang melanggar etika dalam jurnalistik (Rivers \& Mathews, 1988).

Sudah menjadi rahasia bersama bahwa setiap media, baik itu televisi, radio, koran dan media online memegang teguh prinsip "bad news is good news". Istilah ini juga bukan barang baru, semua orang sudah tahu dan paham maknanya. Prinsip "bad news is good news" sudah terlanjur merasuki jiwa dan mendarah daging pada media massa kita saat ini. Sehingga acap kali media lebih mengutamakan kabar buruk demi mengejar rating pembaca dan keutungan semata.

Media yang lebih mengedepankan korban konflik daripada mengangkat perang antara pihak yang bertikai inilah yang disebut sebagai praktik jurnalisme damai. Jurnalisme damai adalah praktik jurnalistik yang bersandar pada pertanyaan-pertanyaan kritis mengenai manfaat aksi-aksi kekerasan dalam sebuah konflik dan hikmah dari konflik itu sendiri (Katahati Institute, 2009).

Peace journalism pertama kali diprakarsai oleh Johan Galtung dari Norwegia. Johan Galtung merupakan seorang veteran mediator damai yang juga pendiri International Peace Research Institute di Oslo (PRIO) pada tahun 1959. Teori Galtung ini dikembangkankan oleh Jake Lynch dan Annabel McGoldrick (Keeble, Tulloch \& Zollman, 2010). Peace journalism atau Jurnalisme damai adalah sebuah konsep baru di bidang akademik, khususnya jurnalisme dan sektor media. Jurnalisme damai diterapkan untuk meredakan meluasnya keresahan, kekacauan dan kekerasan pada suatu pemberitaan. Jurnalisme damai banyak disalah artikan dengan situasi kondisi perang. Padahal jurnalisme damai juga bisa digunakan pada situasi konflik, seperti; bentrokan dan kerusuhan. Ketika ada suatu konflik. maka suatu tayangan berita bisa meminimalisasikan keresahan dan kekerasan bagi khalayak pemirsa televisi. namun faktanya masih ada tampilan tayangan berita konflik secara eksplisit dan detail.

Sejarah singkat jurnalisme damai dimulai pada tahun 1997 ketika Galtung, menyampaikan serangkaian ceramah tentang "Konflik dan Jurnalisme Damai" pada kuliah musim panas di Taplow Court (United Kingdom). Para peserta meliputi para jurnalis, pakar media, dan mahasiswa yang datang dari Eropa, Afrika, Asia, dan Amerika Serikat yang membagi waktu mereka untuk kuliah, lokakarya dan debat. Serangkaian konferensi ikut diselenggarakan di Taplow Court (1997-1999), dan sejak itu jurnalisme damai telah berkembang, teori maupun praktik.

Pelatihan-pelatihan jurnalis telah diselenggarakan di Indonesia, Afrika Selatan, Liberia, Nepal, Kolombia dan Filipina. TRANCEND, jaringan internasional para sarjana dan praktisi perdamaian dan pembangunan, menjalankan kursus-kursus melalui situs dan pelatihanpelatihan online sebagai bagian dari kerja Peace University. Selain itu, institut-institut di Jepang dan Hawai juga menyelenggarakan kursus-kursus dan silabus-silabus tingkat universitas. Jake Lynch dan Annabel McGold rich kemudian menerbitkan buku mereka dalam bahasa Inggris berjudul Peace Journalism (Transcend.org, 2018).

Peace Journalism dapat dimaknai sebagai jurnalistik damai. Kata "jurnalistik" sendiri bermakna ilmu, seni dan keterampilan dalam penyajian atau penyampaian informasi tentang peristiwa aktual dengan menggunakan media komunikasi massa cetak atau elektronik (Nugroho, 1989). Sedangkan kata "damai" bisa disebut sebagai momen di mana terjadi keseimbangan; tanpa adanya salah satu pihak yang menonjol. Singkatnya; win-win solution. 
Jurnalisme damai juga merupakan konsep baru dalam sektor media. Menurut Jake Lynch dari Associate Professor and Director of the Centre for Peace and Conflict Studies, University of Sydney, jurnalisme damai atau peace journalism adalah situasi ketika para editor dan reporter membuat pilihan-mengenai apa yang akan dilaporkan dan bagaimana melaporkannya-yang menciptakan kesempatan bagi masyarakat luas untuk mempertimbangkan dan menilai tanggapan non-kekerasan terhadap konflik (Transcend.org, 2018).

Prinsip jurnalisme damai melaporkan suatu kejadian dengan bingkai lebih luas, lebih berimbang dan lebih akurat yang di dasarkan pada informasi tentang konflik dan perubahan yang terjadi. Sesuai dengan istilah yang dipakai, jurnalisme damai adalah jenis jurnalisme yang lebih mengarah pada penyampaian informasi yang berdampak pada perdamaian. Jake Lynch dan Annabel McGoldrick menyebutkan dalam teori pendukung jurnalisme damai bahwa pelaksanaan peace journalism didasari oleh tekad dan komitmen para redaktur dan wartawannya untuk memilih cara penyelesaian masalah secara damai. Dengan demikian dalam prakteknya kebijakan redaksional peace journalism memilih terlebih dahulu materi berita apa yang akan disiarkan dan bagaimana cara menyiarkan dengan tujuan mencari solusi terciptanya perdamaian (Transcend.org, 2018).

Dalam hal arah peliputan, Galtung menyusun pertanyaan guna mengingatkan para jurnalis untuk tetap berjalan pada arah damai, antara lain: (1) Konflik ini sebetulnya konflik tentang apa? Siapa saja pihak yang terlibat, dan apa tujuan mereka sebenarnya? Hitunglah pihak-pihak di luar arena konflik, di mana kekerasan (jika ada) terjadi! Daftar ini seringkali cukup panjang. (2) Apa akar yang lebih dalam dari konflik ini, dalam struktur dan budaya, termasuk sejarah dari keduanya?. (3) Gagasan -gagasan apa saja yang ada tentang hasil-hasil lain dari konflik ini, ketimbang yang dipaksakan oleh satu pihak terhadap yang lain? Khususnya, ide-ide baru dan kreatif? Dapatkah ide-ide itu diperkuat untuk mencegah kekerasan?. (4) Jika kekerasan terjadi, bagaimana dengan dampak-dampak yang tak terlihat, seperti trauma dan kebencian, dan hasrat untuk pembalasan serta lebih banyak kejayaan?. (5) Siapa yang berupaya untuk mencegah kekerasan, apa visi mereka tentang hasil konflik, serta metode-metode mereka dalam upaya tersebut? Bagaimana upaya mereka itu dapat didukung?. (6) Siapa yang memprakarsai rekonstruksi, rekonsiliasi dan resolusi? Dan siapa yang hanya meraup keuntungan (seperti kontrak-kontrak rekonstruksi)? (Lynch \& McGoldrick, 2005).

Jika pendekatan seperti ini dilakukan, besar kemungkinan konflik yang terjadi di lapangan akan mereda dan memasuki tahap yang lebih tenang. Fokus pada kekerasan salah satu pihak saja hanya akan menyembunyikan konflik sebenarnya, dan menanam bibit bagi lebih banyak kekerasan. Fokus pada hasil-hasil tanpakekerasan, empati pada semua pihak, dan kreativitas, diharapkan akan mewujudkan perdamaian.

Peran jurnalis dalam jurnalisme damai hanyalah melalui karyanya (pemberitaan). Bila ada perang antara dua pihak, sebagai jurnalis kita memberikan kontribusi ke arah perdamaian dengan cara memberitakan hal-hal yang mendukung ke arah perdamaian. Bila kita terlibat sebagai mediator, atau sebagai juru runding, kita bukan lagi seorang jurnalis tetapi pihak yang terlibat dalam konflik. Salah satu ciri adanya berita jurnalisme damai adalah berorientasi pada solusi: perdamaian samadengan tanpa kekerasan yang ditambah dengan kreativitas. Mengangkat inisiatif-inisiatif perdamaian, juga untuk mencegah lebih banyak perang. Fokus pada struktur, budaya, dan masyarakat yang damai. Kesudahan: resolusi, rekonstruksi, rekonsiliasi (Lynch \& McGoldrick, 2005).

Jurnalisme damai lebih mengedepankan empati kepada korban, sehingga topik-topik yang dipilih sebagai bahan berita tidak hanya memaparkan suatu masalah, akan tetapi juga menawarkan sebuah solusi. Pada satu sisi pers berpotensi mempertajam. Namun pada 
jurnalisme perdamaian, media berpotensi untuk menjadi peredam konflik, salah satunya dengan cara membangun opini menyejukkan. Wartawan bertindak memetakan masalah, menganalisa konflik dan mengungkapkan akar persoalan. Wartawan tidak memvonis siapa yang kalah dan menang. Namun, menyelesaikan konflik secara damai, dengan menempatkan kepentingan masyarakat luas, di atas kepentingan kelompok tertentu. Untuk lebih spesifik mengenai peace journalism, dapat dilihat dari tabel berikut ini:

Tabel 1. Perbedaan Jurnalisme Perang dengan Jurnalisme Damai

\begin{tabular}{ll}
\hline \multicolumn{1}{c}{ Jurnalisme Perang } & \multicolumn{1}{c}{ Jurnalisme Damai } \\
\hline Bipolar & Multipolar \\
\hline Tertutup & Terbuka \\
\hline Kita-mereka & Kita-kita \\
\hline Reaktif & Proaktif \\
\hline Melihat dampak yang tampak & Melihat dampak yang tidak tampak \\
\hline Menang-kalah & Menang-menang \\
\hline
\end{tabular}

Jurnalisme damai pada dasarnya adalah upaya meluruskan kembali apa yang menyimpang dalam praktik jurnalisme. Prinsipnya, jurnalisme itu tujuannya untuk kepentingan publik, untuk kebaikan masyarakat luas. Jadi, ketika suatu pemberitaan kemudian tidak memberi kebaikan untuk masyarakat, misalnya karena cara pemberitaannya yang kurang mempertimbangkan bagaimana menyelesaikan konflik atau malah cara pemberitaan itu berpotensi membuat konflik jadi semakin berkepanjangan, maka muncul jurnalisme damai (peace journalism).

Peace journalism adalah upaya mengembalikan jurnalisme ke ruh atau tujuan dasarnya, yaitu kepentingan publik. Perdamaian dan berakhirnya konflik adalah kepentingan publik. Untuk mengambil peran ini, UIN Sulthan Thaha Saifuddin Jambi telah berupaya menyiapkan insan jurnalis yang sesuai tuntutan zaman dengan mendirikan Prodi Jurnalistik Islam. Prodi Jurnalistik Islam Fakultas Ushuluddin UIN Sulthan Thaha Saifuddin Jambi merupakan Prodi yang baru didirikan berdasarkan SK Kementrian Agama Republik Indonesia Nomor 3843 Tahun 2017 tentang Izin Penyelenggaraan Program Studi pada Program Sarjana dan Megister Institut Agama Islam Negeri Sulthan Thaha Saifuddin Jambi. Prodi ini merupakan pengembangan dari kosentrasi Ilmu Jurnalistik (IJ) dibawah prodi Komunikasi dan Penyiaran Islam (KPI).

Lahirnya Program Studi Jurnalistik Islam merupakan harapan baru dalam rangka peningkatan kualitas sumber daya manusia. Prodi ini diharapkan mampu merespon kebutuhan angka kerja profesi jurnalisme dikarenakan tingginya dinamika berbagai aspek kehidupan masyarakat. Kualitas mutu pendidikan menjadi isu yang utama dalam konteks pendidikan di perguruan tinggi, tak terkecuali pada Universitas Islam Negeri (UIN) Sulthan Thaha Saifuddin Jambi. Perguruan tinggi dikatakan bermutu apabila mampu menetapkan dan mewujudkan visinya melalui pelaksanaan misi, serta mampu memenuhi kebutuhan/ memuaskan stakeholders yaitu kebutuhan masyarakat, dunia kerja dan profesional, sehingga, perguruan tinggi harus mampu merencanakan, menjalankan dan mengendalikan suatu proses yang menjamin pencapaian mutu. Sebuah proses pendidikan yang bermutu tentunya harus juga didukung oleh faktor-faktor penunjang proses pendidikan yang bermutu pula.

Tidak mengherankan, jika pada mulanya perguruan tinggi Islam berdiri hanya membuka jurusan pendidikan (tarbiyah), Hukum (syariah) dan Ushuluddin. Kini mulai banyak yang membuka jurusan-jurusan lain yang memang dibutuhkan oleh masyarakat karena pengaruh perubahan zaman, salah satunya adalah Jurusan Ilmu Jurnalistik Islam. 
Saat ini kurikulum yang digunakan adalah kurikulum Kerangka Kualifikasi Nasional Indonesia (KKNI). Mata kuliah yang diajarkan adalah jurnalisme investigasi, jurnalisme radio, televisi dan jurnalisme foto. Dari gambaran matakuliah yang akan diajarkan pada jurusan Jurnalistik Islam, belum terdapat matakuliah peace journalism, padahal matakuliah ini sangat penting untuk diajarkan kepada mahasiswa yang nantinya akan terjun ke masyarakat. Oleh karena itu, penting rasanya untuk mengkaji tema-tema jurnalisme damai (peace journalism) yang mengisi diskusi-diskusi kalangan akademisi baik itu pengamat media, dosen dan mahasiswa khusunya pada jurusan Ilmu Jurnalistik Islam. Bahkan esensi dari peace journalism ini harus merasuk ke dalam jiwa setiap sanubari mahasiswa yang nantinya akan berdedikasi dalam bidang jurnalisme dan sektor media.

\section{Metode}

Berdasarkan pada pokok permasalahan yang diangkat yaitu maka Penelitian ini mempergunakan metode penelitian mixed methods yaitu menggabungkan antara penelitian lapangan, kepustakaan (library research) (Suryabrata, 1989) dan dilengkapi dengan research on the internet (Studygs.net, 2017). Library research dilakukan dengan menelaah naskah, dokumen, arsip, koran, majalah, internet dan buku-buku yang berkaitan dengan topik yang dibahas. Artinya mencari dan mempelajari bahan-bahan tertulis yang berkenaan dengan objek penelitian. Buku-buku yang digunakan berkaitan dengan jurnalistik menjadi sumber rujukan. Karena pembahasan ini terkait dengan Prodi Jurnalistik Islam yang terdapat dalam al-Quran, maka referensi yang akan dipakai meliputi berbagai tafsir, disamping itu juga menggunakan kitab-kitab hadis.

Penelitian ini menggunakan pendekatan kualitatif yaitu menekankan pada pembangunan naratif atau deskripsi tekstual atas fenomena yang diteliti dimana data penelitian berupa data non statistik. Peneliti mencoba menggambarkan dan menganalisa data mulai dari tahap pengumpulan, penyusunan data, serta disertai analisis dan interpretasi terhadap data tersebut (Surakhmad, 1980).

Penelitian kualitatif memiliki lima karakteristik (Nasution, 1998) sebagai berikut: (1) sumber data adalah situasi yang wajar apa adanya dan peneliti sendiri sebagai kunci atau instrumen utamanya; (2) bersifat deskriptif, yakni mendeskripsikan data-data yang dikumpulkan dari hasil rekaman, foto, catatan-catatan, dan lain sebagainya; (3) lebih mengutamakan proses dari pada hasilnya, artinya memprihatikan secara seksama bagaimana perkembangan terjadinya sesuatu pristiwa yang menjadi fokus penelitian; (4) menganalisa data hasil penelitian dengan menggunakan pendekatan induktif dan tidak untuk membuktikan hipotesis; (5) pendekatan kualitatif lebih mengutamakan pengambilan makna dibalik fenomena yang tampak yakni mencari dan mengungkap makna terkandung dibalik suatu peristiwa. Data yang diperoleh dari hasil penelitian ini, adalah data-data verbal yang diambil dari berbagai literatur, baik dalam bentuk buku, surat kabar, majalah, jurnal maupun berupa makalah yang disampaikan pada tingkat nasional, maka menganalisanya dengan deskriptif kualitatif.

\section{Hasil dan Pembahasan}

\section{Urgensi Mata Kuliah Peace Journalism}

1. Kebutuhan Profesi Jurnalisme

Jika di runut dari sejarah, era reformasi telah membawa dampak signifikan terhadap keterbukaan informasi dan perkembangan media baik lokal maupun nasional. Hal ini kemudian memberi peluang bagi menjamurnya perusahaan media, baik cetak atau elektronik, online atau offline. Penambahan jumlah perusahaan media ini tentunya membutuhkan tenaga- 
tenaga profesional di bidang Jurnalistik baik sebagai wartawan, maupun pengelola dibidang industri media.

Lahirnya program studi Jurnalistik Islam di UIN STS Jambi merupakan respon kebutuhan angka kerja profesi jurnalisme yang semakin tinggi tersebut. Peluang ini tentunya tidak hanya dilandasi oleh kepentingan yang pragmatis, melainkan harus juga dilandasi mutu pendidikan itu sendiri. UIN STS Jambi harus menyadari bahwa perguruan tinggi dikatakan bermutu apabila mampu menetapkan dan mewujudkan visinya melalui pelaksanaan misi, serta mampu memenuhi kebutuhan/memuaskan stakeholders yaitu kebutuhan masyarakat, dunia kerja dan profesional termasuk dibidang jurnalisme.

Untuk mewujudkan visi dan misinya tersebut, saat ini Prodi Jurnalistik Islam UIN STS Jambi mengajarkan beberapa matakuliah komponen prodi yang berorientasi pada keilmuan jurnalisme. Untuk lebih jelas dapat dilihat dari tabel berikut ini: (Dokumentasi Kurikulum Prodi Jurnalistik Islam Fak. Dakwah UIN STS Jambi, 2018).

Tabel 2. Daftar Mata Kuliah

\begin{tabular}{cccl}
\hline No & Kode MK & Semester & \multicolumn{1}{c}{ Nama Matakuliah } \\
\hline 1 & JI160001 & I & Dasar-Dasar Jurnalistik \\
\hline 2 & JI160003 & I & Hukum dan Etika Jurnalistik \\
\hline 3 & JI160004 & I & Bahasa Jurnalistik \\
\hline 4 & JI160010 & II & Dasar-Dasar Fotografi \\
\hline 5 & JI160002 & II & Jurnalistik Foto \\
\hline 6 & J1160011 & II & Teknik Reportase \\
\hline 7 & JI160015 & II & Teknik Wawancara. \\
\hline 8 & JI160016 & III & Teknik Penulisan Berita \\
\hline 9 & JI160018 & III & Teknik Penulisan Feature \\
\hline 10 & JI160020 & III & Teknik Penulisan Artikel \\
\hline 11 & JI160019 & IV & Teknik Penyuntingan Naskah (Editing) \\
\hline 12 & JI160021 & IV & Manajemen Media dan Redaksi \\
\hline 13 & JI160022 & IV & Manajemen Pemasaran Media \\
\hline 14 & JI160023 & V & Jurnalistik Radio \\
\hline 15 & JI160024 & V & Jurnalistik TV \\
\hline 16 & JI160025 & V & Jurnalistik Online (Cyber Media) \\
\hline 17 & JI160029 & VI & Broadcasting Radio \\
\hline 18 & JI160028 & VI & Broadcasting TV \\
\hline 19 & JI160026 & VII & Tekhnik Presentasi \& Olah Vokal TV \\
\hline 20 & JI160027 & VII & Tehknik Olah Vokal Radio \\
\hline 21 & JI160017 & VII & Tehk. Peliputan \& Penulisan Berita TV dan Radio \\
\hline
\end{tabular}

Deretan matakuliah ini merupakan kelompok matakuliah komponen prodi, dimana menjadi kewajiban bagi mahasiswa untuk menguasainya. Matakuliah ini juga nantinya akan menjadi bekal mahasiswa jika suatu saat nanti mereka terjun ke bidang jurnalisme yang tentunya menuntut mereka untuk profesional.

Harapan akan lahirnya insan-insan jurnalis yang baik secara kemampuan maupun etika menjadi cita-cita dari Prodi Jurnalistik Islam UIN STS Jambi. hal ini didasari oleh kekhawatiran bahwa banyak insan jurnalis di Indonesia yang terkesan tidak berkompetensi, pragmatis dan tidak memiliki standar mutu kerja. Salah satu yang mendasari hal ini karena banyak para insan jurnalis yang tidak berlatarbelakang pendidikan yang sesuai.

Berbagai profesi di bidang jurnalisme saat ini telah berkembang pesat dan sangat jauh berbeda dengan masa lalu. Peran wartawan sekarang ini sangat dirasakan penting dalam berbagi aspek kehidupan. Selain memberikan informasi kepada masyarakat luas, wartawan 
juga mampu mengangkat seseorang menjadi popular di hadapan publik. Namun, pers harus tetap berpegang pada kebebasan yang bertanggung jawab.

Banyak masyarakat kita berpendapat negatif terhadap profesi wartawan karena di anggap hanya cari duit. Memang munculnya wartawan seperti ini barangkali dikarenakan kurangnya kesejahteraan secara materi yang diperolehnya dari perusahaan media tempat ia bernaung. Hal inilah yang membuat profesi wartawan tidak bekerja secara profesional ditambah lagi tidak adanya latar belakang pendidikan di bidang tersebut sehingga menciptakan wartawan pragmatis yang muncul secara bergerombol dalam mencari narasumber beritanya.

\section{Pemberitaan Konflik Provokatif}

Semestinya pers yang berkualitas selalu berpedoman pada etika, moralitas serta berintelektual dan memiliki kinerja seorang profesional. Sekarang ini penyampaian beritaberita di berbagai media massa memang jelas terlihat begitu bebas dan terbuka dan terkadang pers menampilkan berita melalui gambar-gambar yang terlihat tidak etis dan sadis. Bukan hanya itu, secara sadar atau tidak judul-judul pemberitaan terutama berita terkait konflik atau kerusuhan cenderung provokatif.

Pada konteks konflik ini, seharusnya para jurnalis harus berorientasi pada perdamaian untuk menggali proses terjadinya konflik dan membantu menemukan titik api. Pemaparan liputan diupayakan berorientasi pada situasi sedemikian rupa untuk mendorong agar kedua belah pihak bisa mencapai menang dalam kondisi win-win orientation (Emka, 2005).

Konflik-konflik yang terjadi di tengah masyarakat disebabkan tidak hanya oleh perbedaan kepentingan, namun juga oleh kesalahan komunikasi dan kesalahpahaman di antara berbagai bagian masyarakat (Ispandriarno, Hanitzsch \& Loeffelholz, 2002). Kesalahan dan kesalahpahaman ini tidak terlepas dari peran jurnalis dalam membuat berita. Jurnalis memegang peran penting dalam membuat berita yaitu sebagai interpreter yang menginterpretasikan fakta yang ia lihat dan ia dengar menjadi sebuah berita. Fakta dalam pendekatan konstruksionis dianggap sebagai realitas yang dikonstruksikan. Dalam hal ini manusia secara aktif memberi definisi dan memberikan makna terhadap suatu peristiwa. Dengan demikian fakta itu ada dalam kosepsi pikiran orang (Wardhani, 2012).

Jurnalis bukanlah pemulung yang mengambil fakta begitu saja. Karena dalam kenyataannya, tidak ada realitas yang bersifat eksternal dan objektif yang berada di luar diri jurnalis. Realitas bukanlah sesuatu yang "berada di luar" yang objektif, yang benar, yang seakan-akan ada sebelum diliput oleh jurnalis. Sebaliknya, realitas itu dibentuk dan diproduksi tergantung pada bagaimana proses konstruksi berlangsung. Realitas itu sebaliknya, bersifat subjektif, yang terbentuk lewat pemahaman dan pemaknaan subjektif dari jurnalis (Eriyanto, 2007)

Jurnalisme yang dijalankan media memegang peranan penting, dalam situasi konflik, perang maupun situasi krisis. Ia bisa berdampak positif maupun negatif. Pada satu sisi bisa mendorong terjadinya peperangan, di satu sisi lain dapat mendorong perdamaian. Jurnalisme perang memainkan peran meningkatkan konflik. Sedangkan jurnalisme damai bisa menurunkan konflik.

Pertanyaan besar yang harus terjawab adalah, bagaimana mencegah perang, konflik atau mengurangi dampak negatif yang terjadi akibat perang, konflik melalui kegiatan jurnalisme?. Tentunya pertanyaan ini bisa dijawab dengan menyiapkan sumber daya manusia yang memahami secara konfrehensif bagaimana seharusnya peran jurnalisme.

Menyiapkan sumber daya manusia dibidang jurnalisme yang ideal tentunya bukan perkara mudah. Butuh kerjasama dari berbagai bidang baik pemerintah, masyarakat, maupun 
kampus sebagai garda terdepan. Oleh karena itu penting kiranya memberikan pemahaman kepada mahasiswa tentang apa dan bagaimana peace journalism ini. Sehingga harapanharapan tentang insan jurnalis yang lebih mengedepankan aspek perdamaian dalam setiap pemberitaan dapat tercapai.

\section{Strategi Pengembangan}

1. Perencanaan Kurikulum

Kegiatan perencanaan kurikulum dapat dipahami sebagai pengalaman untuk mempersiapkan peserta didik dalam mencapai tujuan pendidikan, baik yang diperoleh dari dalam maupun luar lembaga pendidikan, maka kurikulum hendaknya melalui fungsi perencanaan yang matang serta sistematis dan terpadu, pengorganisasian yang baik, diimplementasikan di lapangan, dan diawasi pelaksanaannya.

Kurikulum adalah semua pengalaman yang telah direncanakan untuk mempersiapkan peserta didik mencapai tujuan pendidikan baik yang diperoleh dari dalam maupun luar lembaga yang telah direncanakan secara sistematis dan terpadu (Hamalik, 2008). Manajemen dalam perencanaan kurikulum dapat diartikan sebagai keahlian atau kemampuan merencanakan dan mengorganisasi kurikulum. Pokok kegiatan utama studi manajemen kurikulum meliputi bidang perencanaan dan pengembangan kurikulum, pelaksanaan dan perbaikan kurikulum. Manajemen perencanaan dan pengembangan kurikulum berdasarkan asumsi bahwa telah tersedia informasi dan data tentang masalah-masalah dan kebutuhan yang mendasari disusunnya perencanaan secara tepat.

Dalam merancang kurikulum, prodi Jurnalistik Islam sebaiknya lebih menekankan pada berbagai aspek yang meliputi perkembangan, proses, dampak, dan pengelolaan serta pendayagunaan media massa baik yang berbentuk media cetak (surat kabar, majalah), media auditif, maupun media audio visual (TV/ Radio). Pengetahuan dan keterampilan yang diberikan di bidang ini tidak saja menyangkut aspek-aspek teoritis, akan tetapi menyangkut pula aspek teknis atau keterampilan jurnalistik. Selain itu, prodi Jurnalistik Islam dapat mempersiapkan mahasiswa calon sarjana yang dapat mempraktekkan kemampuan berwirausaha di bidang komunikasi, kantor berita, ataupun menjadi pengajar dan peneliti di bidang jurnalistik.

Bagi kampus atau Perguruan Tinggi Islam, jurusan jurnalistik harus bernilai plus, yakni plus visi-misi Islami. Tujuan perkuliahan jurnalistik di kampus Islam hendaknya (1) Memberdayakan umat Islam di bidang jurnalistik. (2)Mengembangkan syi'ar Islam melalui dakwah di media massa. (3) Menggali potensi umat Islam untuk melakukan dakwah di media massa. (4) Mempersiapkan dan membina kader-kader dakwah via media massa yang andal, minimal mampu menggerakkan buletin jumat di masjid-masjid. (5) Mendorong lahirnya media massa Islam, paling tidak dalam bentuk buletin masjid (buletin jumat) di masjidmasjid. (6) Memberikan wawasan dan keterampilan jurnalistik, berupa penulisan berita, feature, artikel, resensi, dan pengelolaan buletin masjid.

Salah satu matakuliah wajib bagi mahasiswa jurnalistik adalah peace journalism. Peace journalism memiliki prinsip-prinsip yang sama dengan Jurnalisme Islami, yakni memiliki misi mewujudkan perdamaian sebagaimana cita-cita agama Islam diturunkan. Salah satu contoh item yang senada dengan prinsip jurnalisme damai adalah menghindarkan prasangka buruk maupun pemikiran yang negatif terhadap kenyataan objektif berdasarkan pertimbangan yang adil dan berimbang (Khoiruzzaman, 2016). Pada matakuliah peace journalism, Rencana Pembelajaran Semester (RPS) dapat dilihat dari uraian berikut: 


\section{a. Deskripsi}

Mata kuliah ini bertujuan untuk menghasilkan kompetensi mahasiswa di bidang Peace Journalism (Jurnalisme damai), khususnya jurnalistik di bidang konflik. Peserta didik akan memiliki kompetensi dalam pengorganisasian ilmu Peace Journalism, mampu melakukan tahapan jurnalistik, mampu menggunakan software sebagai alat bantu, mampu membuat pemberitaan mengenai konflik yang berorientasi pada Peace Journalism.

\section{b. Model Pembelajaran}

Mata kuliah ini diselenggarakan dengan menggunakan 3 model pembelajaran dari model pembelajaran yang tersedia dalam model pembelajaran KBK KKNI, yaitu "Contextual Instruction", "Small Group Discussion" dan "Project Based Learning". Ketiga model pembelajaran ini melibatkan mahasiswa secara aktif mengembangkan pengetahuan dan membuat mahasiswa menjadi pusat pembelajaran. Metode Contextual Instruction mengharuskan mahasiswa membahas konsep dan teori yang diajarkan dosen dan menghubungkannya dengan fakta di lapangan atau fakta di organisasi/ perusahaan yang akan diteliti. Small Group Discussion mengharuskan mahasiswa kelas membentuk kelompok diskusi, membahas bahan diskusi, dan secara bergantian menjadi juru bicara dan presentasi. Diluar kelas, mereview materi kuliah sebelumnya dan materi kuliah minggu berikutnya. Project Based Learning mengharuskan mahasiswa mengamati fenomena sehingga mampu membuat laporan dan kesimpulan untuk dipresentasikan.

Tabel 3. Buku Acuan Utama

\begin{tabular}{cl}
\hline No & \multicolumn{1}{c}{ Judul Buku } \\
\hline 1 & $\begin{array}{l}\text { Galtung, J and Vincent, R (1992) Global Glasnost - Toward a new world information and } \\
\text { communication order? Cresskill, NJ: Hampton Press }\end{array}$ \\
2 & $\begin{array}{l}\text { Galtung, J, Jacobsen C \& Brand-Jacobsen K (2002) Searching for Peace - The Road to } \\
\text { TRANSCEND: Pluto Press }\end{array}$ \\
3 & $\begin{array}{l}\text { Susan Dante and Majid Tehranian (2017) Peace Journalism in Times of War: Volume 13: Peace } \\
\text { and Policy. Routledge, New York }\end{array}$ \\
4 & $\begin{array}{l}\text { Ibrahim Seaga Shaw, Jake Lynch, Robert A. Hacket (ed), (2011) Expanding Peace Journalism: } \\
\text { Comparative and Critical Approaches. Sidney University Press }\end{array}$ \\
5 & $\begin{array}{l}\text { J. Anto dan Pemilian Perdede (ed), (2007) Meretas jurnalisme damai di Aceh: kisah reintegrasi } \\
\text { damai dari lapangan. Jakarta: Yayasan Obor Indonesia }\end{array}$ \\
6 & $\begin{array}{l}\text { Iswandi Syahputra, Indonesia (2006), Jurnalisme damai: meretas ideologi peliputan di area } \\
\text { konflik. Jakarta: Pilar Media }\end{array}$ \\
7 & $\begin{array}{l}\text { Annabel McGoldrick (2011), Jurnalisme damai: bagaimana melakukannya?, Lembaga Studi } \\
\text { Pers dan Pembangunan (LSPP) }\end{array}$
\end{tabular}

c. Pelaksanaan Perkuliahan dan Penilaian

Kuliah ini akan dilaksanakan dalam waktu 14 kali tatap muka yang terdiri dari 7 pertemuan sebelum Ujian Tengah Semester (UTS) dan 7 pertemuan setelah UTS. Evaluasi terhadap prestasi mahasiswa dilaksanakan dalam 2 kali ujian yaitu UTS dan UAS . Nilai akhir untuk setiap mahasiswa merupakan akumulasi nilai-nilai sebagai berikut: Komposisi Penilaian: Tugas (20\%), UTS (30\%), dan UAS (50\%). Grade nilai terdiri dari Nilai A (80100), Nilai B $(66-79,99)$, Nilai C $(56-65,99)$, Nilai D $(46-55,99)$ dan Nilai E $(0-45,99)$. Nilai $\mathrm{A}, \mathrm{B}$, dan $\mathrm{C}$ lulus, sedangkan nilai $\mathrm{D}$ dan $\mathrm{E}$ tidak lulus dan wajib diulang.

d. Materi Perkuliahan

Adapun tema-tema perkuliahan yang dapat di tawarkan pada mata kuliah peace journalism ini antara lain: 
Islam Melalui Mata Kuliah Peace Journalism

Tabel 4. Materi dan Sub-Materi Perkuliahan

\begin{tabular}{|c|c|c|}
\hline No & Materi & Sub materi \\
\hline 1 & $\begin{array}{l}\text { Dasar-dasar pemahaman } \\
\text { peace journalism }\end{array}$ & $\begin{array}{l}\text { a. Sejarah Peace Journalism } \\
\text { b. Definisi Peace Journalism } \\
\text { c. Ciri-Ciri Adanya Berita Jurnalisme Damai } \\
\text { d. Karakteristik Jurnalisme Damai }\end{array}$ \\
\hline 2 & Memahami Konflik & $\begin{array}{l}\text { a. Mengapa Belajar Konflik? } \\
\text { b. Apa itu konflik? } \\
\text { c. 'Konflik' tidak sama dengan 'Kekerasan' } \\
\text { d. Situasi konflik } \\
\text { e. Hasil konflik } \\
\text { f. Pendekatan untuk Konflik } \\
\text { g. Pendekatan kompetitif } \\
\text { h. Pendekatan kooperatif atau kolaboratif } \\
\text { i. Apa yang membuat pendekatan kompetitif lebih } \\
\text { mungkin? } \\
\text { j. Apa yang membuat pendekatan kooperatif lebih } \\
\text { mungkin? }\end{array}$ \\
\hline 3 & Memahami Kekerasan & $\begin{array}{l}\text { a. Kekerasan Langsung } \\
\text { b. Kekerasan Budaya } \\
\text { c. Kekerasan Struktural } \\
\text { d. Efek Terlihat dan Terlihat dari Kekerasan } \\
\text { e. Siklus Kekerasan }\end{array}$ \\
\hline 4 & Memahami Damai & $\begin{array}{l}\text { a. Tanpa kekerasan } \\
\text { b. Dari mana asal perubahan? } \\
\text { c. Negosiasi Sosial }\end{array}$ \\
\hline 5 & Media dan Konflik & $\begin{array}{l}\text { a. Dunia cerdas dunia } \\
\text { b. Pihak-pihak dalam konflik merencanakan } \\
\text { langkah selanjutnya berdasarkan pada apa yang } \\
\text { akan diliput media } \\
\text { c. Apakah Anda bagian dari strategi media? } \\
\text { d. Semua jurnalisme adalah intervensi } \\
\text { e. Literasi damai } \\
\text { f. Objektivitas } \\
\text { g. Dunia baru 'media global' } \\
\text { h. Konsekuensi persaingan } \\
\text { i. Untuk apa wartawan itu? } \\
\text { j. Survei Global tentang hambatan bagi wartawan } \\
\text { k. Sejarah singkat Jurnalisme Perdamaian } \\
\text { l. Publikasi, pelatihan, dan pendidikan }\end{array}$ \\
\hline 6 & $\begin{array}{l}\text { Praktik peliputan Peace } \\
\text { Journalism }\end{array}$ & $\begin{array}{l}\text { a. Sebelum Kekerasan Langsung } \\
\text { b. Awal Kekerasan } \\
\text { c. Pesta Tidak Berkomunikasi } \\
\text { d. Bagaimana Jika Anda Hanya Dapat Melaporkan } \\
\text { Pada Satu Pihak? } \\
\text { e. Pelaporan Pembantaian } \\
\text { f. Pelaporan tentang Pengungsi } \\
\text { g. Jalan buntu } \\
\text { h. Proposal Perdamaian }\end{array}$ \\
\hline
\end{tabular}

\section{Penyiapan Sarana Praktik}

Jurnalistik adalah ilmu terapan (applied science). Karenanya, perkuliahan jurnalistik mesti praktek untuk mengasah keterampilan jurnalistik mahasiswa. Sarana praktek wajib disediakan oleh manajemen jurusan, seperti ruang multimedia. Jurnalistik adalah ilmu terapan (applied sience) sekaligus seni (art) dan keterampilan (skill) yang membutuhkan medium pelatihan sebagai sarana pengembangan dan pengasahan keterampilan. 
Dengan memberikan perhatian pada aspek ilmu dan teknis jurnalistik tersebut, diharapkan para lulusan bidang studi jurnalistik mempunyai kemampuan akademis yang profesional di bidangnya. Dengan demikian para lulusan/sarjana Jurnalistik akan dapat mengaplikasikan ilmunya baik dalam hal produksi (penulisan dan perencanaan), penelitian dan pengelolaan media massa seperti dalam bidang persuratkabaran, radio maupun televisi/ film.

Perkuliahan mahasiswa jurnalistik harus ditunjang oleh sarana praktik untuk meningkatkan pemahaman dan penguasaan teknik jurnalistik sehingga mahasiswa lulusan jurnalistik akan "siap pakai" (ready to work). Idealnya, selain blog atau situs khusus untuk menampung karya jurnalistik mahasiswa, jurusan jurnalistik menerbitkan media konvensional seperti tabloid atau surat kabar (media cetak).

Selain sebagai media praktik, penerbitan media praktik juga berfungsi untuk mengasah nalar dan kritisisme mahasiswa, sekaligus sarana ekspresi idealisme mahasiswa dalam lingkungan kampusnya (Pers Kampus). Penerbitan media praktik otomatis sangat menunjang pelaksanaan kurikulum Kerangka Kualifikasi Nasional Indonesia (KKNI) karena mahasiswa tidak hanya berkutat di bangku kuliah untuk mendalami konsep-teoritis, namun juga langsung mempraktikkannya di lapangan untuk memupuk kompetensi mereka sebagai jurnalis.

Media praktik itu bermisi sebagai media pelatihan sekaligus media ekspresi mahasiswa untuk mengkritisi fenomena yang terjadi di sekitarnya secara objektif, proporsional, ilmiah, santun, dan elegan. Selain itu, misi media praktik ini sebagai penunjang sistem perkuliahan berdasarkan sistem KKNI, mencetak lulusan jurnalistik yang "siap pakai" dan bersaing di dunia kerja, juga sebagai media informasi dan komunikasi harmonis dan efektif antar mahasiswa jurnalistik, organisasi mahasiswa jurusan, lembaga jurusan dan dosen.

\section{Pembelajaran Berbasis Pengalaman Langsung}

Program Studi Jurnalistik Islam Fakultas Dakwah UIN STS Jambi bertujuan menghasilkan lulusan yang mampu bekerja sebagai jurnalis multiplatform, multimedia content producers, serta researcher di bidang jurnalisme konvergensi. Melalui metode pembelajaran berbasis pengalaman langsung, mahasiswa diajak untuk melakuan ekplorasi terhadap bentuk-bentuk baru jurnalisme, seperti virtual reality journalism, augmented reality journalism, data journalism, drone journalism, visual journalism, mobile journalism dan lainlain.

Pembelajaran berbasis pengalaman langsung dapat di laksanakan dengan cara magang di berbagai sektor media, seperti (1) Jurnalis multiplatform yang mampu beradaptasi dengan lingkungan pekerjaan media televisi, radio, cetak, online, bahkan konvergensi. (2) Praktisi media seperti: producer program tv dan radio, camera person, floor director, production assistant, penyiar tv dan radio serta jurnalis foto. (3) Multimedia Content Producers dengan jiwa kewirausahaan yang mampu mengembangkan bisnis konten untuk memenuhi kebutuhan industri media dan korporasi terhadap konten-konten multimedia. (4) Researcher yang mampu melakukan riset kajian ilmu jurnalistik sekaligus juga mampu melakukan riset praktis dalam pengembangan produk baru jurnalisme dan evaluasi terhadap produk-produk jurnalisme. (5) Menguasai perubahan yang disebabkan oleh keberadaan ICT dan teknologi multimedia. Mahasiswa dilengkapi dengan fundamen ilmu komunikasi yang mantap dan keterampilan mengolah informasi dengan berbagai tools multimedia dengan tujuan memberikan citra positif bagi perusahaan/organisasi tempat dia bekerja. 


\section{Simpulan}

Dari pembahasan di atas dapat disimpulkan bahwa urgensi mata kuliah Peace journalism bagi pengembangan keilmuan prodi Jurnalistik Islam meliputi: adanya kebutuhan profesi jurnalis yang semakin besar sebagai sebuah konsekuensi dari era keterbukaan informasi saat ini. Untuk menjawab tantangan ini profesi jurnalisme menjadi sangat krusial tanpa mempertimbangkan pengetauan akademik secara ke ilmuan. Peluang ini tentunya tidak hanya dilandasi oleh kepentingan yang pragmatis, melainkan harus juga dilandasi mutu pendidikan itu sendiri. Secara umum insan jurnalis di Indonesia terkesan tidak berkompetensi, pragmatis, dan berlatarbelakang pendidikan yang sesuai. Selain itu pemberita-pemberitaan yang di sajikan oleh di banyak media saat ini bersifat provokatif dan tidak mengedepankan perdamaian. Sangat jelas bahwasanya matakuliah yang di terima oleh mahasiswa untuk menjadi seorang jurnalis harus sesuai dan tepat sasaran agar profesionalisme jurnalis dapat terbentuk.

Strategi pengembangan keilmuan program studi Ilmu Jurnalistik Islam Melalui Mata Kuliah Peace Journalism, antara lain melaui kegiatan perencanaan kurikulum, penyiapan sarana praktik, dan pembelajaran berbasis pengalaman langsung. Kegiatan perencanaan kurikulum dapat dipahami sebagai pengalaman untuk mempersiapkan peserta didik dalam mencapai tujuan pendidikan. Jurnalistik adalah ilmu terapan (applied science). Karenanya, perkuliahan jurnalistik mesti praktek untuk mengasah keterampilan jurnalistik mahasiswa. Sarana praktek wajib disediakan oleh manajemen jurusan, seperti ruang multimedia.

\section{Referensi}

Emka, Z, A. (2005). Wartawan Juga Bisa Salah: Etika Pers dalam terapan, Surabaya: Stikosa-Aws

Eriyanto. (2007). Analisis Framing: Konstruksi, Ideologi dan Politik Media. Yogyakarta: LkiS

Hamalik, O. (2008). Manajemen Pengembangan Kurikulum, (Jakarta: Remaja Rosda Karya.

Hikmat, M, M. (2018). Jurnalistik: Literary Journalism. Jakarta: Prenademedia Grup.

Ispandriarno, L, S., Hanitzsch, T \& Loeffelholz, M. (Ed). (2002). Media-Militer-Politik, Crisis Communication: Perspektif Indonesia dan Internasional. Yogyakarta: Friedrich E.S dan Galang Press.

Katahati Institute (2009). Merangkai Kata Damai. Banda Aceh: Katahati Institute.

Keeble, R., Tulloch, J \& Zollman, F (editor). (2010), Peace Journalism, War and Conflict Resolution. New York: Peter Lang Publiser.

Khoiruzzaman, W. (2016). Urgensi Dakwah Media Cyber Berbasis Peace Journalism Jurnal Ilmu Dakwah, Vol. 36(2) 2016 EISSN 2581-236X, 15.

Kusumaningrat, H \& Kusumaningrat, P. (2009). Jurnalistik Teori \& Praktik. Bandung: Remaja Rosdakarya.

Lynch, J \& McGoldrick, A. (2005). Peace Journalism. Australia: Hawthorn Press.

Lynch, J \& McGoldrick, A. Peace Journalism What is it? How to do it?, Diakses pada tanggal 22 Juni 2018 melalui: $\underline{\text { https://www.transcend.org/ }}$ tri/downloads/McGoldrick_Lynch_Peace-Journalism.pdf

Lynch, J. What Is Peace Journalism?. Diakses pada tanggal 22 Juli 2018 melalui https://www.transcend.org/tms/about-peace-journalism/1-what-is-peace-journalism/

Masduki. (2007). Regulasi Penyiaran: dari Otoriter ke Liberal. Yogyakarta: LkiS

Nasution. (1998). Metode Penelitian Naturalistik. Bandung: Tarsito.

Nugroho, E. (1989). Ensiklopedi Nasional Indonesia. Jakarta: Cipta Abadi Pustaka.

Ramdan, A. (2016). Jurnalistik Islam. Yogyakarta: Shahara Digital Publising. 
Republik Indonesia, Undang-Undang Penyiaran, no 32 tahun 2002, pasal 4.

Research On The Internet. Diakses pada tanggal 30 Oktober 2017 melalui: http://www.studygs.net/research.htm

Rivers, W, L \& Mathews, C. (1994). Ethic for The Media diterjemahkan oleh Arwah Setiawan dan Danan Priyatmokop, dengan judul Etika Media. Jakarta: Gramedia.

Sumadiria, H. (2008). Jurnalistik Indonesia Menulis Berita dan Feature. Bandung: Simbiosa Rekatama Media.

Surakhmad, W. (1980). Pengantar Penelitian Ilmiah. Bandung: Tarsito

Suryabrata, S. (1989). Metodologi Penelitian. Jakarta: Rajawali Press.

Syahputra, I. (2006). Jurnalisme Damai: Meretas Ideologi Peliputan di Area Konflik. Yogyakarta: Pilar Media.

Tim Penyusun Kamus Pusat Pembinaan dan Pengembangan Bahasa (1989). Kamus Besar Bahasa Indonesia (Jakarta: Departemen Pendidikan dan Kebudayaan.

Wardhani, A, C. (2012). Jurnalisme Perang dan Kontribusi Jurnalisme alternatif untuk perdamaian. 